\title{
Lack of Legal Protection for Beneficiary Creditors of Fiduciary in The Bankruptcy of Debtor in Indonesia
}

\author{
Siti Malikhatun Badriyah ${ }^{1}$, Siti Mahmudah ${ }^{2}$, Kashadi $^{3}$ \\ \{ sitimalikhatun@live.undip.ac.id ${ }^{1}$ \} \\ Faculty of Law, Diponegoro University, Semarang $1,2,3$
}

\begin{abstract}
Fiduciary guarantee is one of the collaterals that are often used in society, especially in business activities. The primary function of the guarantee is to provide receivables security of creditors. Beneficiary Creditors of Fiduciary have positioned preferred and separatist creditors. However, in the practice of dispute often arises because of differences of interpretation as regards the legal consequences for Beneficiary Creditors of Fiduciary in bankruptcy of debtor. This study aims to reveal the evidence as well as provide analysis on legal consequences as well as lack of legal protection for creditors of the fiduciary guarantee in bankruptcy of the debtor. Theory and concepts that are used are the basic ideas of law, Rechtsvinding, justice, Progesif Law, Legal Protection, Agreements, Collateral, and bankruptcy. The results of the research showed that if the debtor bankrupt's creditors of the fiduciary recipient can do execute fiduciary guarantee object. It is set firmly in the fiduciary guarantee legislation. However in practice often arise problems if the debtor bankrupt, due to differences of interpretation especially if associated with Bankruptcy Law and debt repayment Obligations that determine the existence of waiting time for Creditors in performing execution of fiduciary guarantee object. As a result, it is often the beneficiary creditor of fiduciary less gets legal protection.
\end{abstract}

Keyword: Legal Protection, Fiduciary Guarantee, Bankruptcy, preferred, separatist, execution

\section{Introduction}

The fiduciary guarantee is one of the collaterals that is often used in society, especially in business activities. This is because fiduciary guarantees provide benefits and convenience for the parties. For creditors, fiduciary guarantees can be used to guarantee the safety of their credit. The other hand, debtor or fiduciary giver, has the right to authorized the corresponding object. In this fiduciary guarantee given to beneficiary creditor of fiduciary is ownership rights over objects. Fiduciary guarantees are fundamental in the interests of the existence of bad credit. According to [1], high credit growth is associated with an increase in the ratio of bad loans. Bad credit can cause the bankruptcy of individuals. [2], arguing that bankruptcy prediction is a challenging problem in corporate finance. [2] states that the prediction of bankruptcy companies is a significant thing.

Article 1 point 1 of Act Number 42 of 1999 concerning Fiduciary Guarantees states that "Fiduciary is the transfer of ownership rights of an object based on trust provided that objects whose ownership rights are transferred remain in the authority of the owner of the object." 
"Fiduciary guarantee is a guaranteed right for movable objects both tangible and intangible, and immovable objects, especially buildings that cannot be encumbered with Underwriting Rights that remain in the control of the Fiduciary Giver, as collateral for certain debt repayments, which give priority to Beneficiary of Fiduciary of other creditors " (Article 1 point 2 of the Fiduciary Guarantee Act).

From the above definition, it can be seen that fiduciaries are distinguished from fiduciary guarantees [3]. A fiduciary is a process of transferring ownership rights, while fiduciary guarantees are guarantees given in the form of fiduciary. The transfer of ownership rights here is not intended to be onward, but only as collateral for the debt. This ownership right will return to the Fiduciary Giver if the debt has been repaid.

As one of the collateral, the beneficiary creditor of fiduciary is the preferred creditor and separatist creditor. The beneficiary of Fiduciary is individuals or corporations that have accounts receivable whose payment is guaranteed by a Fiduciary Guarantee (Article 1 point 6 of the Fiduciary Guarantee Act). Preferred creditors have preferential rights, namely the right to take precedence in repaying their receivables compared to other creditors. Separate creditors are creditors who are not affected by the debtor's bankruptcy.

Article 27 Paragraph (3) of the Fiduciary Guarantee Act states that the prioritized rights of the Fiduciary Beneficiary are not removed due to bankruptcy and or liquidation of the debtor. From Article 55 Paragraph (1) of Act Number 37 of 2004 concerning Bankruptcy and Postponement of Obligations of Debt Payments (Bankruptcy Act) states that every mortgage creditor, fiduciary guarantee, mortgage, mortgage or collateral rights over other collateral, can execute the right as if there was no bankruptcy.

Even though there is a provision that if the debtor is bankrupt then separatist creditors can exercise their rights as if there were no bankruptcy, but in practice, there are often problems between separatist creditors and curators. These problems are mainly related to the 90-day stay as stipulated in the Act of Entitlement and rejection from the curator (Article 56 Paragraph (1) Bankruptcy Act). Creditors of collateral holding (including beneficiary of fiduciary) must exercise their rights within a period of no later than 2 (two) months after the start of the state of insolvency as referred to in Article 178 paragraph (1) of the Bankruptcy Act, which often leads to conflicts between creditors and curators, even to lawsuits, resulting in beneficiary creditors of fiduciary becoming less protected by law.

Based on the description above, the research that aims to reveal the evidence of legal consequences and legal protection for creditors if the debtor is bankrupt is very urgent to be carried out.

\section{Material and Method}

\subsection{The Concept of Fiduciary Guarantees}

The principle of guarantee is contained in Article 1131 and Article 1132 of the Civil Code. The term "guarantee" is a translation of the term zekerheid or cautie, namely the ability of debtors to fulfill or pay off debts to creditors, which is carried out by holding certain objects of economic value as collateral for loans or debt received by debtors to creditors [4].

The guarantee function is to guarantee the safety of creditors' receivables [5]. In Article 1131 of The Civil Code states that all the material of a debtor, both movable and immovable, 
both existing and new, will be available at a later time, as a guarantee for the personal engagement of the debtor.

According to [6], from Article 1131 K.U.H. The Civil Code can be seen that every person is responsible for his debt, this responsibility is in the form of providing his wealth both movable and immovable objects (fixed objects), if necessary to pay off his debts (Schuld and Haftung principles). This principle is very fair, by the principle of trust in the law of engagement, that is, everyone who gives a debt to someone believes that the debtor will fulfill his or her future achievements. Everyone is also obliged to fulfill his promise as a moral principle which is established by the legislators as a legal norm., from Article 1131 of The Civil Code can be seen that every person is responsible for his debt, this responsibility is in the form of providing his wealth both movable and immovable objects (fixed objects), if necessary to pay off his debts (Schuld and Haftung principles). This principle is very fair, by the principle of trust in the law of engagement, that is everyone who gives a debt to someone believes that the debtor will fulfill his or her future achievements. Everyone is also obliged to fulfill his promise as a moral principle which is established by the legislators as a legal norm.

In Article 1131 of The Civil Code is put on the general principle of the right of a creditor to debtor [7]. Thus, all of the debtor's assets are collateral for debtors' debts to creditors. The general principle contained in Article 1131 is described further in Article 1132 of The Civil Code. From the regulation of Article 1132 of The Civil Code can be seen that if there are several creditors, the position of creditors is the same (crematorium parity principle). If wealth is insufficient to pay off debtor's debts, the creditors get a payment based on the principle of balance. Creditors get balanced payments according to the size of the accounts of each creditor. Thus the general principle is contained, namely the equal rights of creditors to the assets of the debtor.

General guarantees still lack legal protection for creditors, because the position of each creditor is the same. In this regard, individual guarantees are needed. The law deviates from the principle of balance as mentioned above, namely if there is an agreement or if the act determines it. This deviation of the principle of balance can be seen from Article 1132 of The Civil Code.

These legitimate reasons are deviations from general principles or principles of balance, namely as stated in Article 1133 of The Civil Code if there are receivables with privileges, pawns, and mortgages. The accounts receivable must be prioritized.

Thus, creditors of collateral holding have a position as preferred creditors and separatist creditors. Separate creditors are creditors who are not affected by the debtor's bankruptcy. One of collateral that is carried out in practice and experiencing rapid development is a fiduciary guarantee.

[8] state that the elements of Fiduciary guarantee are namely (a) fiduciary guarantee is a guaranteed right, (b) the subject of the fiduciary guarantee is the Fiduciary Giver and Fiduciary Beneficiary, (c) objects of fiduciary collateral are movable and immovable objects that cannot be burdened with mortgages or mortgages, (d) the transfer of ownership rights to an object from the Fiduciary to the Fiduciary Recipient on the basis of trust, (e) Objects of the Fiduciary Guarantee remain in the power of the Fiduciary Giver with borrowing, and (6) Provide a position that is preferred to Fiduciary Recipients against other creditors

\subsection{The concept of bankruptcy}

Bankruptcy comes from the words 'bankrupt' in French failing' [9] or 'failliet' in Dutch, which means strikes or payment bottlenecks. So, the word 'bankrupt' in Indonesian can be interpreted 
as a state of stopping paying, as stated in Article 1 number 1 of Law No. 37 of 2004 concerning Bankruptcy. H.M.N Purwosutjipto stated that Bankruptcy is everything related to bankruptcy events. Subekti and R. Tjitrosoedibio explained that after the person who is at the request of his creditors or his request by the Court is declared bankrupt, his assets are controlled by the Treasury Office as curatrice (bankruptcy) to be used for all creditors [10].

The conditions for submitting a bankruptcy statement against a debtor can be seen in Article 2 paragraph (1) of the Bankruptcy Act which states that a debtor has two or more creditors and does not pay off at least one debt that has fallen due and can be billed - declared bankrupt with a court decision, both at the request of one or more creditors.

Article 55 (1) UUK and PKPU With due regard to the provisions referred to in Article 56, Article 57, and Article 58, each creditor holding pawn, fiduciary guarantee, encumbrance right, mortgage or collateral rights over other material, can exercise his rights as if there is no bankruptcy. In Article 55 Paragraph (2) UUK \& PKPU it is stated that in the case of a collection of a receivable as referred to in Article 136 and Article 137 then they can only do so after the billing has been matched and only to make repayment from the amount recognized from the collection.

\section{$3 \quad$ Method}

The research method used is legal pluralism that integrates philosophical, normative and sociological research. This research reveals legal principles integrated with laws and regulations and practices in people's lives related to fiduciary guarantees and bankruptcy.

\section{Discussion}

\subsection{Legal impact of the fiduciary beneficiary if the debtor is bankrupt}

Fiduciary guarantees are collateral, because they fulfill the characteristics of material rights, namely (1) the object is a good; (2) raises material rights; (3) absolute, (3) the existence of revindication rights (i.e., the right to claim material that is the object of fiduciary guarantee if there is a disturbance); (4) has the nature of droit de suite, namely material rights always follow the object in the hands of whomever it is; (5) Having a droit de preference, meaning giving a prior position to material rights holders.

As a material guarantee, fiduciary guarantees have many advantages in law because creditors have a special preference, so they get the priority on the results of the execution of collateral for the payment of debts before other debts. The fiduciary guarantee is a guaranteed right that is strong and easy to implement. Fiduciary Beneficiary has a separatist position, which is not affected by the debtor's bankruptcy.

Bankruptcy is a condition in which the debtor is unable to make payments to the debts of his creditors. The situation of being unable to pay is usually due to the difficulty of financial conditions (financial distress) from the business of debtors who have experienced setbacks.

Bankruptcy causes the Debtor to lose its right to legally authorize and manage its assets which are included in bankrupt assets since it was declared bankrupt, as regulated in Article 24 paragraph (1) of the Bankruptcy Act. Bankruptcy causes all binds of the debtor after the verdict of the bankrupt cannot be paid from the bankrupt property, except the binds benefit the property (Article 25 of the Bankruptcy Act). All of the Debtor's bankrupt assets are managed by the 
Curator under the supervision of the Supervisory Judge. This is by Article 1 point 1 of the Bankruptcy Act.

Creditors can submit bankruptcy applications if they fulfill the following conditions (a) the debtor has two or more creditors, and (b) the debtor is not paying at least one debt that has fallen due and can be collected.

The existence of collateral makes the creditor holder of collateral a position as Preferred Creditors and Separatist Creditors, so they can execute such guarantees as if no bankruptcy occurs. According to Intan Cahya W et al. (2016) [11] separatists are connoted with separation, because the position of creditors is separated from other creditors. Fiduciary creditors can sell themselves and pay off their receivables from the proceeds of the sale.

In a fiduciary guarantee, the object of guarantee is in the hands of the fiduciary giver. In the event of bankruptcy, the fiduciary beneficiary should be able to execute immediately. Article 27 paragraph (3) of the Fiduciary Guarantee Act states that the rights preceded by Beneficiary of Fiduciary are not deleted due to bankruptcy and or liquidation. This provision is in line with Article 55 Paragraph (1) of the Bankruptcy Act which states that "every pawn holder, fiduciary guarantee, Encumbrance Right, mortgage or another collateral right, can execute his rights as if there was no bankruptcy". However, Article 56 (1) states that "The right of execution of creditors and the rights of third parties to claim their assets under the authorize of bankrupt debtors or curators are suspended for a maximum period of 90 (ninety) days from the date of the pronounced bankruptcy statement".

If we see the collateral principle is an exclusive guarantee that provides convenience in execution, should the debtor bankruptcy be executed immediately without waiting for the completion of the standstill / automatic stay? The fiduciary creditor as the preferred creditor and separatist creditor, the object of fiduciary collateral should be a separate object, not in bankruptcy property, then in accordance with Article 27 Paragraph 3 of the UUJF in conjunction with Article 55 Paragraph (1) of the Bankruptcy and PKPU Act no need to wait for standstill / automatic stay.

Article 58 of The Bankruptcy Act states that creditors holding collateral must exercise their rights within a period of no later than 2 (two) months after the start of the state of insolvency. After two months, the curator must demand that the object which is collateral be sold for sale, without reducing the creditor's right to the sale of the collateral. Each time the Curator can free objects that are collateral by paying the smallest amount between the market price of the collateral object and the amount of debt guaranteed by the collateral object to the relevant creditor.

Article 60 of the Bankruptcy Act states that creditors holding collateral to carry out their rights must give responsibility to the Curator about the sale of objects that are collateral and submit the remaining proceeds after deducting the amount of debt, interest, and fees to the Curator. For the demands of a privileged Curator or Creditor whose position is higher than the right-holders Creditors, the Creditor holding the right must submit a portion of the proceeds of the sale for an amount equal to the amount of the privileged bill. If the proceeds of the sale are insufficient to pay off the receivables in question, the creditor of the right holder can submit a settlement bill for the shortfall from the bankrupt assets as the concurrent creditor, after submitting the request for matching accounts.

In bankruptcy, Creditors must register all bills to the Curator with evidence supporting the validity of the invoice as stated in Article 115 of Law Number 37 Bankruptcy Act that states:

(1) All Creditors must submit their respective receivables to the Curator accompanied by calculations or other written statements indicating the nature and amount of the receivables, accompanied by a letter of proof or copy, and a statement of whether or 
not the creditor has a privilege, lien, fiduciary, encumbrance right, mortgage,

collateral rights for other material, or the right to hold objects.

(2) For the delivery of receivables, the Creditors have the right to request a receipt from the Curator.

Bills that have been registered will be received and recorded by the Curator and then classified according to the position of Creditors. These bills are then matched and entered into the Creditors List, and the bills will be included in the list of receivables that are recognized or denied.

The invoices that are included in the list of debts that are denied are given a reason why the bills are denied as stated in Article 117 of Bankruptcy Act. The Curator must include the receivables agreed to in a temporary list of accounts recognized, while the debts which are denied including the reasons are included in the separate list ".

Creditor registration must be done as a form of billing the debtor to the Debtor so that the Curator can classify the position of Creditors in bankruptcy, whether as Preferred Creditors, Separatist Creditors or Concurrent Creditors, so that the Curator in carrying out his duties when the bill payment or bankrupt boedel distribution is clear the position and status of the bills registered by the creditor.

The list of creditors will be read by the Supervisory Judge in the Tax Verification Meeting and the Matching of Receivables regulated in Article 124 paragraph (1) of the Bankruptcy Act. The Supervisory Judge reads out the list of receivables received temporarily and lists of accounts that are denied by the Curator.

In practice, ask for bills submitted by Separatist Creditors that are denied or not approved by the Curator even though by the Debtor. These conditions often occur in a lawsuit between Separatist Creditors and Curators related to collateral items.

\subsection{Legal protection for fiduciary beneficiary creditors if the debtor is bankrupt}

The law is dynamic (histories estimate), always follows developments. In its development, the law sought ideally, namely the realization of three basic ideas in the law, namely legal certainty (rechtssicherkeit), benefit (zweckmassigkeit), and justice (gerechtigkeit). These three elements by Gustav Radbruch are said to support the ideals of the law (idee des Rechts). This legal ideal will guide people in their legal life. Legal protection for fiduciary beneficiary creditors can be seen from their rights and obligations in bankruptcy of debtors.

As a separatist creditor, he can execute the object of fiduciary guarantee in the event of a bankrupt debtor. This is regulated in Article 27 Paragraph (3) of the Fiduciary Guarantee Act in conjunction with Article 51 of the Bankruptcy Act. This arrangement is very appropriate because objects that should be objects of fiduciary guarantee become separate assets from bankruptcy assets. However, it turns out that in the practice of selling objects of fiduciary guarantee as stipulated in the Bankruptcy Act must wait until the period of automatic stay ends. The automatic stay period is 90 days from the bankruptcy decision. The automatic stay period is confirmed in Article 56 of the Bankruptcy Act. As a separatist creditor, Beneficiary Fiduciary was not affected by the debtor's bankruptcy, so that in the event of a bankruptcy the debtor could execute as if there was no bankruptcy. The existence of automatic stay has reduced the creditor's rights, thus indicating a lack of legal protection for creditors receiving material guarantees.

As a Preferred creditor, the repayment of the sale of the object of fiduciary guarantee can be repaid before other creditors. If the object of fiduciary collateral is insufficient to pay off 
creditors' receivables, it can submit a settlement bill for the shortfall from bankrupt assets as concurrent creditors, after submitting a request for matching account receivables.

In the Bankruptcy Act, implementation of the execution of fiduciary guarantee objects must be carried out at the latest 2 (two) months after the start of the state of insolvency. After two months, it must be submitted to the curator for subsequent sale, without reducing the creditor's right, the holder of the collateral rights for the sale of the collateral. Provide a report to the curator after executing the object of fiduciary guarantee. If there is a remainder, it must return to the curator.

The limitation on the sale of objects of fiduciary guarantee reduces the rights of fiduciary beneficiary creditors as separatist creditors. Moreover, the 2-month period is a period that is too short for the sale of corresponding objects. This shows that there is very little legal protection for creditors of the fiduciary beneficiary.

\section{Conclusion}

As a separatist creditor, it should not be affected by the debtor's bankruptcy, but in practice, there are still differences of views due to the automatic stay and the limits of execution. Fiduciary creditors lack legal protection in the event of debtor bankruptcy.

\section{Acknowledgment}

Our sincere appreciation is according to Rector of Diponegoro University; Dean of Law Faculty, Diponegoro University; LPPM of Diponegoro University; Committee of ICBLP, and do to all of the people, we can present our paper, Narotama University, Sidoarjo, 13 to 14 February 2019.

\section{Reference}

[1] H. Hilmy, S. A. Mohd, · Norasyikin, and A. Fahami, 'Factors Affecting Bankruptcy: the Case of Malaysia', Int. J. Undergraduates Stud., vol. 2, no. 3, pp. 4-8, 2013.

[2] S. Ramakrishnana, M. Mirzaeib, and M. Naveedc, 'Corporate Bankruptcy Prediction: A Case of Emerging Economies', Int. J. Sci. Basic Appl. Res., vol. 19, no. 1, p. 177187., 2015.

[3] W. D. Suryandari, 'Reconstruction Of Legal Liability Of Registration By Notary Fiduciary Based On PP No. 21 of 2015', J. Pembaharuan Huk., vol. V, no. 2, AprilAugust, p. 252-261., 2018.

[4] R. Usman, Hukum Jaminan Keperdataan,. Jakarta: sinar grafika, 2008.

[5] S. M. Badriyah, 'Problematic of Fiduciary Guarantee in the Consumer Finance Agreement Without a Notarial Deed', Int. Jaurnal Humanit. Soc. Stud., vol. 3, no. 6, pp. 284-288, 2015.

[6] Mariam Darus Badrulzaman, Mencari Sistem Hukum Benda Nasional,. Bandung: Alumni, 1983.

[7] T. Kamelo, Hukum Jaminan Fidusia Suatu Kebutuhan yang Didambakan. Bandung: Alumni, 2006. 
[8] siti malikhatun Badriyah, Sistem Penemuan Hukum dalam Masyarakat Prismatik (Rechtvinding System in Prismatic Societies). semarang: sinar grafika, 2016.

[9] R. Hartini, Hukum Kepailitan, Edisi Revisi. Malang: Penerbit Universitas Muhammadiyah Malang, 2017.

[10] Subekti and Tjitrosoedibio, Kamus Hukum. Jakarta: Pradnya Paramita.

[11] I. C. W, E. Susilowati, and R. Suharto, 'Akibat Hukum bagi Kreditor Separatis Pemegang Hak Jaminan Fidusia pada Kepailitan Perseroan Terbatas (Studi Kasus Putusan MA 4/PK/ PDT.SUS-PAILIT/2014', Diponegoro Law Rev., vol. 5, no. 2, pp. $1-14,2016$. 